\title{
ROLE OF THE CIVIL SOCIETY FOR ECONOMY
}

\author{
Iryna Tkachuk \\ Affiliated Honorary Research Fellow \\ Fil. Dr. Jan-U. Sandal Institute \\ 31 Kløverveien, Finstadjordet, Norway, 1475 \\ SHEI "University of Banking" \\ 1 Andriivska str., Kyiv, Ukraine, 04070 \\ Tkachuk.Iryna.IT@gmail.com
}

\begin{abstract}
The aim of the article is to shed light upon the essence and functions of the civil society, as well as to outline the features of its functioning.

The article considers the views of thinkers of the past and modernity on the essence and significance of civil society, which formed the basis of a modern understanding of its content and role in the development of democracy and society. Also, modern approaches to the interpretation of the content of this concept were reviewed.

It is revealed, that those approaches to the interpretation of the civil society of thinkers of the past and present, which take into account its component as economy, were and remain the most studied and time-consuming ones, and eventually do not lose their relevance.

The main functional models of civil society are highlighted. It is justified, that the extended functional model, formed on the basis of the models of Merkel-Lauth and Edwards, more fully reflects the functions, performed by the civil society.

Different models of interaction of civil society, state, business, family are investigated. It is proposed to consider the civil society as an environment that enables the interaction of the state, business and family in accordance with their natural functioning.

Keywords: Civil society, NGOs, Democracy, Business, State, Family, Merkel-Louth model, Role Model of Edwards, Christoph Spurk's functional model, Civil society institutions.
\end{abstract}

DOI: $10.21303 / 2504-5571.2019 .00944$

\section{Introduction}

The current reality is characterized by rapid changes in the conditions of the functioning of national economies and powerful accumulation of arrays of new information, requiring the subjects of the economy to possess extreme adaptability and flexibility. In such a situation, not only traditional factors are affecting the development of economies and social and economic growth (labor resources, means of production, and natural resources) but also completely new ones, which create a pivotal base for the functioning of these economies. One of these factors is the formation of a modern developed CS, because it is the basis for the formation of interrelations and relationships between all social and economic phenomena and processes, determines their essence, quality and character, based on the traditions of the constitutional state (and the high level of development of the CS is possible only under the condition of the existence of a state, governed by law).

In Ukraine as an independent state, the problems of the existence and development of civil society have always been the subject of discussion by scholars, politicians and journalists. Such discussions were intensified the most during the periods of the development of democracy (the beginning of the 90's, the Orange Revolution of 2004-2005, the Revolution of Dignity of 2013-2014, etc.).

Ukrainian and foreign scholars have paid considerable attention to these problems in their numerous works.

Thus, a special contribution to the study of the CS was made by such foreign scientists as Croissant A., Edwards M., Habermas J., Hegel F., Laut H., Locke J., Marx K., Merkel U., Montesquieu C.-L., Putnam R., Spurk C., Tocqueville A. These scientists prepared the theoretical and practical basis for further research of the existing of the CS and activities of its institutions. Thus, in the 17th century, Locke J. divided political and civil societies [1, 2]. Montesquieu C.-L. developed the theory of John Locke by dividing the notions of political and social society, while emphasizing the importance of maintaining a balance between them [1]. Hegel F. regarded CS as a historical product of economic modernization and the bourgeoisie-driven economy, located 
between the spheres of state and family [3]. Ironically, Marx K. also acknowledged the existence of CS, however, he saw its development only in the organic unity with the bourgeoisie [4]. Tocqueville A., exploring independent institutions as part of CS, called them schools of democracy. Subsequently, Putnam R. called the civic virtues, on which these organizations should be built, social capital [5]. Also important was the study by Habermas J., who, in his research on CS, emphasized its importance for the functioning of the public sphere. These studies have become the theoretical basis for further scientific research, which was later developed by modern researchers. Thus, Merkel U., Laut H., Croissant A., Spurk C., Edwards M. developed these theories and began to explore CS through the lens of its functions and subjects that are carriers of the ideas and values of CS [1, 6-9].

Nowadays, the CS is still the object of research for a huge amount of scientists. For example, Butkeviciene E., Vaidelyte, E., \& Snapstiene, R. focused on the discussion about the role of civil society in local governance and attempts to provide the answers to the questions: who is responsible for and should initiate the partnership between civil society organizations and local government? What are possible partnership models? How are public administrators affected by or do they affect civil society? What are the determinants of active civic participation in local governance? [10]. Cooper R. regarded the role and value of the CS in epy modern world (investigation is devoted to these aspects of functioning of the CS in 2018) [11]. Lewis D. highlighted the peculiarities of interaction between the CS and authoritarian State [12]. Lorch J. and Bunk B. (2016) identified five patterns 6 according to which authoritarian regimes can use civil society for legitimation purposes [13]. Munene J. W. (2017) gave attention to CSOs' role in the promotion of community participation in governance [14]. Silverman B. (2015) investigated the role of the CS in the USA [15]. Paget D. Z. (2017) highlighted the role of civil society organizations in European Health policy [16].

Modern Ukrainian scholars such as Filyk N. [17], Khomiakov L. [18], Polishchuk O. [19], Rabinovych P. [20], Rozova T. [21] also paid some attention to CS, giving their own explanation of its essence and value. However, we should note, that usually their vision of CS was similar to the interpretation, made by thinkers of the past. Thus, Filyk N. emphasizes CS relations with the state, based on the principles of democracy and law [17]. Khomiakov L. sees CS as a "Western civilization" which, through democratic institutions, ensures the functioning of universal values [18]. Polishchuk O. separates CS from the sphere of the state [19]. Rabinovych P. developed his own vision of CS, studying its particular institutions, which perform the functions, entrusted to the CS [20]. Rozova T. views CS through the lens of a historical struggle between the individual and the state [21].

However, most of attention of the above mentioned scholars was given either to studying the problem of CS existing in general or its particular aspects, such as historical, political, legal, social, cultural, etc. It can be explained by the fact that the CS has nearly always been the object of study in these directions. At the same time, such an important component of the $\mathrm{CS}$ as the economic one has remained virtually out of the attention for most scholars or has not been studied to the fullest. We are solely interested in the economic component of the CS, its role and place in the formation and development of the CS. However, before moving on to its study, we believe that, first of all, it is appropriate to consider the theoretical foundations of the CS.

However, despite the achievements of the above-mentioned scholars, it cannot be said that the CS has been fully studied, since most.

The aim of the article is to shedlight upon the essence and functions of the CS, as well as to outline the features of its functioning.

\section{Materials and methods of research}

To achieve the goal of the article, a number of tasks must be performed, namely:

1. To highlight the approaches to interpreting the essence of civil society by the thinkers of the past and the present and to distinguish in them an economic component. 
2. To consider the actor-oriented and functional approaches to the interpretation of civil society at the special stage of development of science.

3. To explore the role of civil society in interaction with the state, business and family.

To achieve the goal of the article, a number of methods of scientific research were used, namely: analysis (in the study of different approaches to the interpretation of the essence of the civil society and its role in the development of the state and economy); comparison (to study the advantages and disadvantages of classifying methods of the functions of the civil society); graphic (to illustrate the boundaries of civil society interaction with areas such as the state, business, family); induction and deduction (when drawing conclusions).

The information and methodological basis of the study was the work of domestic and foreign scientists, data of the global Internet.

\section{Results and discussions}

During different stages of the existence of mankind the role of man and the state in society were considered to be quite different. Accordingly, approaches to comprehension and interpretation of the CS were also different.

The concept of "CS" as an independent term began to be used only in the $17^{\text {th }}-18^{\text {th }}$ centuries. Although philosophical ideas, close in content to this concept, were revealed much earlier by such philosophers as Plato and Aristotle. Aristotle was the first one to use the concept of "CS" as a derivative of the word "citizen" and meant a society of citizens who are free and educated [22].

Most of the modern approaches to the definition of the CS are predetermined by the contribution of philosophers of the past. Information on the thinkers, whose contributions are the most significant and crucial, and their views on the CS are presented in Table $\mathbf{1 .}$

Several conclusions can be drawn from a brief description of the main principles of the CS, summarized in Table 1: firstly, different meanings and interpretations of the CS influenced further theoretical debates and empirical studies of the essence and significance of the CS; secondly, the CS is an almost entirely Western concept, historically linked to the political emancipation of citizens from former feudal ties, and the monarchy and the state during the $18^{\text {th }}$ and $19^{\text {th }}$ centuries. Other CS concepts that could exist in other regions or at different times are practically not reflected in the international debate on the issue of the CS. As a result, nowadays there are discussions about whether the concept of CS can be transmitted in non-Western countries or in other historical contexts with different levels of democracy and economic structures; and finally, most importantly, one can observe underlying economic concepts in all the fundamental theoretical concepts of the CS in one way or another. All of them, regardless of the nature of their origin, are directly connected with the CS, while, in many respects, the way a certain philosopher perceives the CS influences the vision of these economic concepts whether the protection of property rights in the works of John Locke, or the particular features of the action of the compensatory power of social intermediaries in relation to the state in the works of Charles-Louis de Montesquieu, or the market economy in the works of Friedrich Hegel and the bourgeoisie as the basis of the CS in the works of Karl Marx, or the influence of the institutes of the CS on the formation of the social capital in the works of Alexis de Tocqueville, or the oppositional role of the CS to the state and the market in the works of Antonio Gramsci, or the advocacy of marginal groups of their interests (including the economic ones) at the state level in the works of Jürgen Habermas.

In our opinion, the philosophical concepts of the past have had a significant impact on the formation of a modern view of the essence and significance of the CS. Thus, nowadays there are many definitions of the concept of the "CS", which not only vary greatly, but also cover various aspects of it. The contents of the main of those that exist in the Ukrainian science are reflected in Table 2, as they are the reflection of objective processes in the formation of the CS of Ukraine. 
Table 1

Fundamental theoretical concepts of civil society and their philosophical origins*

\begin{tabular}{|c|c|}
\hline Philosopher & Philosophical views on civil society \\
\hline $\begin{array}{l}\text { John Locke } \\
(1632-1704)\end{array}$ & $\begin{array}{l}\text { Was the one, who made a conditional division between the political society (regulates relations between the } \\
\text { citizens and the government) and civil society (regulates relations between the citizens). Civil society is an } \\
\text { area, separate from the state, owning its own rights. People form a community, in which their life goes on, } \\
\text { and in which the state does not have the right to vote. This sphere is primarily political or non-political. The } \\
\text { most important task of civil society is the protection of personal rights and property from the state and } \\
\text { its arbitrary interference }[1,2]\end{array}$ \\
\hline $\begin{array}{l}\text { Charles-Louis } \\
\text { de Montesquieu } \\
(1689-1755)\end{array}$ & $\begin{array}{l}\text { He developed his model of separation of powers (De l'esprit des lois 1748), in which, like Locke, he divided } \\
\text { civil and political society. However, unlike Locke, he saw a much less contrast between these spheres. He } \\
\text { emphasized the balance between the central government and social networks (the body of media- } \\
\text { tors), where the central government (monarchy) should be controlled by the rule of law and limited to the } \\
\text { compensatory force of independent organizations (networks) that work both inside and outside the political } \\
\text { structure [1] }\end{array}$ \\
\hline $\begin{array}{l}\text { Friedrich Hegel } \\
\quad(1770-1831)\end{array}$ & $\begin{array}{l}\text { Considered civil society not as a natural expression of the will, but as a historical product of economic } \\
\text { modernization and a bourgeoisie-driven economy, located between the spheres of state and family [3]. } \\
\text { Civil society consists of a large number of subjects, including the market economy, social classes (includ- } \\
\text { ing the bourgeoisie), large corporations, intellectuals and civil servants, that is, all social actors that do } \\
\text { not depend directly on the state (in Hegel's time). Hegel emphasized that all subjects of civil society are in } \\
\text { constant opposition, and therefore, for the sake of their common existence, it must be under the control of a } \\
\text { strong state (in modern time, meaning a strong law-governed state) [3] }\end{array}$ \\
\hline $\begin{array}{c}\text { Karl Marx } \\
(1818-1883) \\
\text { Engels Fridrih } \\
(1820-1895)\end{array}$ & $\begin{array}{l}\text { Noted that "civil society can only develop along with the bourgeoisie and defined that this concept in- } \\
\text { cludes all the interaction of material relations between individuals at a certain stage of the development } \\
\text { of productive forces" [4]. As in the teachings of Hegel, such an approach involves a large number of sub- } \\
\text { jects, including the economy and the market. However, unlike Hegel, he sees "the basis of a capitalist } \\
\text { model of domination, which is subject to and governed by the state; the latter thus becomes the institution of } \\
\text { the ruling class in civil society" [4]. Civil society is a structural basis, and the state is a superstructure that } \\
\text { provides capitalist domination with the help of power }\end{array}$ \\
\hline $\begin{array}{c}\text { Alexis de } \\
\text { Tocqueville } \\
(1805-1859)\end{array}$ & $\begin{array}{l}\text { The role of independent associations as part of civil society was emphasized [23]. Considered them as } \\
\text { schools of democracy, in which democratic thinking, attitudes and behavior are assimilated in order to } \\
\text { protect personal rights from potentially authoritarian regimes and the tyrannical majority in society. These } \\
\text { associations should be built on a voluntary basis and at all levels (local, regional, and national). Thus, such } \\
\text { civic virtues as "tolerance, acceptance, honesty, and trust are truly integrated into the character of citizens, } \\
\text { contributing to trust and confidence", or, as Putnam later described it, social capital [5] }\end{array}$ \\
\hline $\begin{array}{l}\text { Antonio Gramsci } \\
\quad(1891-1937)\end{array}$ & $\begin{array}{l}\text { Considered civil society through the lens of Marxist theory. He emphasized the potentially oppositional role } \\
\text { of civil society, separated from the state and the market, in which ideological hegemony is challenged. } \\
\text { "Civil society has a wide range of organizations and ideologies. And what is more, both the former and the } \\
\text { latter create a challenge to the existing system, while supporting it. The political and cultural hegemony of } \\
\text { the ruling class and the social consensus is formed within the framework of civil society" }\end{array}$ \\
\hline $\begin{array}{c}\text { Jürgen Habermas } \\
\qquad(1929)\end{array}$ & $\begin{array}{l}\text { Has concentrated his concept on the role of civil society within the public sphere. The political system needs } \\
\text { articulation of interests in the public space in order to present different interests on the political agenda, but } \\
\text { this function cannot remain entirely to create institutions such as political parties. Marginal groups, in partic- } \\
\text { ular, want to find a way to defend their interests. This is necessary because political parties and parliaments } \\
\text { should „receive informed public opinion beyond established defense and law enforcement agencies" [24] }\end{array}$ \\
\hline
\end{tabular}

Note: *-compiled by the author

Therefore, we may see that some of the thinkers of the past and present distinguish such a component of the CS as economic, while others (we consider it necessary to indicate that there is a minority of those who think that way) leave it out of sight. At the same time, we cannot help but note that the theories, that take it into account in the study of the CS, were and remain the most studied and time-consuming ones, and eventually do not lose their relevance.

In accordance with the aforementioned theories in the literature there are two approaches to the interpretation of the CS. The first - the actor-oriented model - focuses on the participants of the CS (participants), while the second - the functional - focuses on the functions that it performs. 
Table 2

The essence of the main approaches to the interpretation of the CS in the Ukrainian science*

\begin{tabular}{|c|c|}
\hline Author & Contents \\
\hline Polishchuk O. & $\begin{array}{l}\text { views CS as "a society, separated from the state (as a political institution), which is based on the sphere of } \\
\text { non-state relations"[19] }\end{array}$ \\
\hline Rozova T. & $\begin{array}{l}\text { believes that ,in the modern sense of the CS is a complex of unified historical experience of resolving the } \\
\text { contradictions between man as a social being and the state as a political entity through the socialization of } \\
\text { the state in the case of non-mandatory politicization of a person"[21] }\end{array}$ \\
\hline Pukhkal O. & $\begin{array}{l}\text { understands the CS as a „symbolic field, branching out of social institutions, practices and values that en- } \\
\text { compasses a set of basic social characteristics and parameters of social viability, which in its turn is separat- } \\
\text { ed from the state and is self-organized” [25] }\end{array}$ \\
\hline Rabinovych P. & $\begin{array}{l}\text { considers CS in the context of the „,state of a social and democratic type", within which it receives a whole } \\
\text { new meaning: „CS is a community of free, equal people and their associations, that are provided with the } \\
\text { legal opportunities to be the owner, as well as take an active part in political life, by the state ,[20] }\end{array}$ \\
\hline Filyk N. & $\begin{array}{l}\text { notes that ,in terms of theory, CS is considered to be a society with developed economic, political, spiritual } \\
\text { and other relations and connections, that interacts with the state and functions on the principles of democ- } \\
\text { racy and law" [17] }\end{array}$ \\
\hline Sokolov V. & $\begin{array}{l}\text { when studying the phenomenon of the CS, pays particular attention to the elements of consolidation, merg- } \\
\text { ing, unification of individuals, transforming groups of people into a society. However, noting the role of such } \\
\text { a social characteristic of a citizen as ownership and freedom of business, notes that it cannot be considered } \\
\text { an absolute element of consolidation [26] }\end{array}$ \\
\hline Khomiakov L. & $\begin{array}{l}\text { understands CS as ,social, political and cultural reality, known as Western European civilization, in which } \\
\text { social welfare, freedom and the rights of citizens are provided by an effective system of democratic institu- } \\
\text { tions" [18] }\end{array}$ \\
\hline Soliar S. & $\begin{array}{l}\text { points out that the "sphere of free communication of participants of public relations, based not on the family } \\
\text { connections, but the goal to realize certain common interests (such as political, social, economic, cultural } \\
\text { interests etc.), outside the public authority institutions, should form the foundation for stable forms of such } \\
\text { communication" [27] }\end{array}$ \\
\hline
\end{tabular}

Note: * compiled by the author on the basis of above mentioned sources

The actor-oriented model focuses on the peculiarities and effectiveness of the activity of specific subjects of the CS, thus neglecting the other components of it. It should be noted that the disadvantages of this model have been proven by many foreign scientists [28], while it still remains popular and is being studied by different scholars in Ukraine. Thus, O. Polishchuk considers the CS and the state as partners, defining the priority of society in this partnership, and notes that the state must exist for the sake of society, and not vice versa [19]. O. Chuvardynskyi and L. Novoskoltseva pay particular attention to the interest groups within the CS (political parties, lobbying organizations, pressure groups, cliques, etc.), describing them as voluntary associations of citizens, created for expressing and satisfying their interests in relations with various political institutions, first and foremost, with the state $[29,30]$.

Thus, the priority role of the $\mathrm{SC}$ and groups of interests in it in the process of interaction with other subjects can still be observed in the national scientific approach. However, given the fact that this model lost its role in leading national scientific researches and leading world researches, we will pay more attention to the functional model.

We believe that today the essence of the functional model is most fully disclosed in two models of the CS: the Merkel-Lauth model and the Edwards model [10].

The Merkel-Lauth model is the result of long-term research by the European school of thought. It discloses the CS not as a specific historical form but as an analytic category $[1,6,7]$. In this model there are 5 specific functions of the CS, the main essence of which is reflected in the Table 3. 
Table 3

The essence of CS functions according to the Merkel-Lauth*

\begin{tabular}{|c|c|c|}
\hline No. & Function & Essence \\
\hline 1 & $\begin{array}{l}\text { Protection of the private } \\
\text { sphere of citizens }\end{array}$ & $\begin{array}{l}\text { Citizens have certain rights and can organize their own lives without the interference of the } \\
\text { government. The task of the CS within this function is to „remind" the state of its role, to limit } \\
\text { its influence on the private sphere within the legal limits }\end{array}$ \\
\hline 2 & $\begin{array}{l}\text { Mediation between the } \\
\text { state and citizens }\end{array}$ & $\begin{array}{l}\text { CS aims to maintain a balance between the central government and social networks in order } \\
\text { to ensure the rule of law }\end{array}$ \\
\hline 3 & Participatory socialization & $\begin{array}{l}\text { CS and its associations are so-called „schools of democracy”. In the developed CS people } \\
\text { learn the basic principles of democracy, learn to be citizens and defend their rights, which in } \\
\text { turn also leads to decentralization of power }\end{array}$ \\
\hline 4 & $\begin{array}{l}\text { Building the community } \\
\text { and integration }\end{array}$ & $\begin{array}{l}\text { participation in the activity of the NGOs helps to overcome social divisions, creates civil vir- } \\
\text { tues, and promotes social cohesion in meeting the social needs of individuals. However, the } \\
\text { basic condition is the certainty that self-organization of citizens is not carried out on the basis } \\
\text { of purely religious, ethnic or racial characteristics }\end{array}$ \\
\hline 5 & Public communication & $\begin{array}{l}\text { is the main function of the CS because it emphasizes the importance of the existence of a free } \\
\text { public sphere, separated from the state and the economy, where individuals have the opportu- } \\
\text { nity to discuss and participate in independent decision-making }\end{array}$ \\
\hline
\end{tabular}

Note: * compiled by the author on the basis of $[1,6,7]$

It is quite obvious, that these functions are not mutually exclusive, but rather complement each other. For example, in accordance with the function of protection of the private sphere of citizens, CS also provides the protection of their economic rights and freedoms; in accordance with the function of mediation between the state and citizens it ensures the rule of law, which makes it possible to protect them; in accordance with the function of participatory socialization it teaches citizens social and economic literacy, teaches them to uphold their rights (including economic ones); in accordance with the function of building the community and integration it helps to overcome social divisions, helps to meet the social needs of individuals. We believe that the function of public communication is also fundamental to the economy, because, despite the formation of a free public sphere, separated from the state and the economy, in which individuals have the opportunity to discuss any topic, to make decisions independently; such a free public sphere is the basis for the formation and existence of an environment, in which it is possible to achieve and secure the above-mentioned rights.

However, it should be noted, that in different periods of social development, the value of some functions may be basic, comparing to others.

Edwards actor-oriented model (role model). The British researcher and activist Michael Edwards, in his turn, also tried to structure the CS. Thus, having understood that different people see it differently [8], he structured the CS, according to the three roles that it performs: CS as an associative life, CS as a good society, and CS as a public sphere.

$\mathrm{CS}$ as an associative life acts as the world of voluntary NGOs, serving as peculiar catalysts for the development of such values as tolerance and cooperation.

Within the role of CS as a good society, associative life is exposed in the right context, strengthening specific positive norms and values, emphasizing that activities within the CS should be aimed at achieving a specific social or political goals.

The role of the CS as a public sphere of the CS is manifested in the creation of such a public space within which individuals can communicate about important things for them, freely debating, thereby constantly developing a sense of interest in social and universal issues. The role of the $\mathrm{CS}$ as a public sphere is central when it comes to the need to find solutions to urgent problems in society and to make informed decisions on their basis. According to Edwards, it is precisely it that is central to the CS and is crucial for the democratic interaction of subjects of social and political relations [8].

The basic idea of the Edwards model is that none of these roles alone can achieve the necessary social and economic changes and other positive results that are traditionally attributed to 
the CS. Thus, the author calls for the integration or synthesis of all roles and their comprehensive consideration in the process of providing CS initiatives [8]. We consider this approach to be correct, because it allows to balance out the strengths of some roles and weaknesses of the others.

Analyzing both of the above-described models, one can conclude that most of their basic provisions coincide, which has led to further research of both models together. With the development of CS theory, much attention has been paid to cooperation between CS institutes and other sectors. Thus, a new approach, based on the expansion of the functions of the CS, has emerged, and it allows a deeper understanding of its contents and meaning. In this way, there are not 5 main CS functions, as was the case with the Merkel-Lauth model, but 7 [9] (Table 4).

\section{Table 4}

Extended CS functions in Christoph Spurk's functional model

\begin{tabular}{|c|c|c|}
\hline No. & Function & Essence \\
\hline 1 & Protection of citizens & $\begin{array}{l}\text { the basic function of the CS, which consists of protecting life, freedom and property from } \\
\text { despotism and attacks by the state and its authorities }\end{array}$ \\
\hline 2 & Reporting and Monitoring & $\begin{array}{l}\text { is mainly to monitor the activities of central authorities, the state apparatus and the govern- } \\
\text { ment. Monitoring is also a means of managing public authorities and forcing them to be held } \\
\text { accountable }\end{array}$ \\
\hline 3 & $\begin{array}{l}\text { Propaganda and public } \\
\text { relations }\end{array}$ & $\begin{array}{l}\text { CS's ability to articulate interests (especially those of marginalized groups) and to create } \\
\text { communication channels to raise citizens' awareness and facilitate discussion }\end{array}$ \\
\hline 4 & Socialization & $\begin{array}{l}\text { CS promotes the formation of democratic relations between citizens. People are learning to } \\
\text { develop tolerance, mutual trust and the ability to find a compromise within democratic proce- } \\
\text { dures. Thus, democracy is ensured not only by legal institutions, but also by citizens' habits }\end{array}$ \\
\hline 5 & Building the community & $\begin{array}{l}\text { the involvement and participation of citizens in the activities of non-governmental organiza- } \\
\text { tions contributes to the formation of social capital. And in cases where one organization has } \\
\text { representatives of different social groups, ethnic and religious affiliations, it helps to elimi- } \\
\text { nate social splits and fosters social unity }\end{array}$ \\
\hline 6 & $\begin{array}{l}\text { Mediation and assistance } \\
\text { between citizens and the } \\
\text { state }\end{array}$ & $\begin{array}{l}\text { CS and its institutions act as a balance of power and negotiations with the state at different } \\
\text { levels (local, regional, national) through the formation of various relationships (communica- } \\
\text { tion, negotiation, control) of different interest groups }\end{array}$ \\
\hline 7 & Provision of services & $\begin{array}{l}\text { the direct provision of services to citizens is an essential component of the activities of NGOs. } \\
\text { Providing services serves as a „starting point" for other CS functions }\end{array}$ \\
\hline
\end{tabular}

Note: * - compiled by the author on the basis of $[1,6,8,9]$

As we can see from Table 4, the extended functional model, formed on the basis of the models of Merkel-Lauth and Edwards, more fully reflects the functions, performed by the CS, nevertheless, the economic component (protection of freedoms and property; monitoring of the activities of central authorities (including that part of it, concerning the legislation in the spheres of the economy and the budget and its implementation), raising citizens' awareness (forming economic literacy), socialization (forming habits of citizens to social activity, including economic one), forming social capital; forming relations of different interest groups, providing direct public services; remains important and visible in almost each of the defined functions.

Therefore, we consider a functional approach to be much more favorable for in-depth analysis and understanding of CS in relation to the economic sphere than the actor-oriented model. This is primarily due to all the CS subjects (including non-urban communities, religious or ethnic organizations, as well as organizations related to purely non-political industries, but sometimes play a significant role in the CS as, for example, business, that can lobby for the authorities in order to achieve its own goal). Thus, a functional approach, due to its completeness, can take into account considerably more details than any other approach. In addition, in our opinion, the functional approach is best, for example, when it comes to the need for interstate comparison, since the functions, performed by CS in different social and political conditions, are much easier to reduce to a common denominator than those of its subjects. 
Like any theory that has a long history, the theory of CS in its development has undergone a certain evolution, therefore, it is obvious, that today the vision of CS differs substantially from that of what it was 100 years ago. For the convenience of studying the phenomenon of CS in the second half of the $20^{\text {th }}$ century, the professor at the University of California, Jeffrey Alexander, identified three stages of the CS, which are conventionally called "CS-I" (the $17^{\text {th }}$ and first half of the $19^{\text {th }}$ century), "CS-II" (in the middle of the 19th and the second half of the 20th century), and "CS-III" (our time) [31].

Even early conceptions of CS-I (J. Locke, A. Ferguson, S. Montesquieu, I. Kant, F. G. Hegel, A. de Tocqueville) distinguished the main element of the economic sphere within it. As within its boundaries, certain individuals could function as independent entities of public activity, which sought to reduce (or even eliminate) the state's interference in their cause, aided by the market mechanisms. The creation and implementation of laws that were the embodiment of the general will of the citizens, protected the inviolability of their rights and freedoms, were the functions of the state.

In our opinion, the allocation of the economic sphere in the CS is appropriate, as it allows to conduct in-depth studies of the interconnections and interdependencies between processes and phenomena, as well as between subjects of both spheres, without diminishing any of them.

This connection of the category of "CS" with industrial relations and economic development was also pointed out by K. Marx, who in the preface to the "Critique of Political Economy" wrote that legal relations, as well as the forms of state, are based on in the material life relations, which Hegel called "CS", as well as the fact that "anatomy of CS should be sought in political economy" [32].

Thus, it can be assumed that it was the desire of the bourgeoisie for freedom that served as the push for the formation of a more modern CS. The further spread of civil and political rights, first to the bourgeoisie, and then to the working class, created the conditions for the integration of these classes into the existing society. According to Yu. Pavlenko, the development in the $20^{\text {th }}$ century, can be considered as a new important stage in the process of formation of a modern CS [33]. We cannot help but agree with this opinion, because it is the high level of social integration, characteristic of the beginning and the middle of the $20^{\text {th }}$ century, that became the basis for not only rapid social and economic development, but also for the CS in general.

"CS-I, II, III" are historical models, but there are other models that basically have the functions that the CS performs. Thus, Nancy Rosenblum identifies "democratic", "intermediary" and "electoral" CS (Table 5).

Table 5

The essence of the "democratic", "intermediary" and "electoral" CS*

\begin{tabular}{cll}
\hline No. & CS & \multicolumn{1}{c}{ Essence } \\
\hline 1 & Democratic & $\begin{array}{l}\text { is characterized by the participants' emphasis on political participation and the potential } \\
\text { opposition of public associations to power structures (counterbalance function) } \\
\text { directs the citizens to maintain social ties, adhere to the principles of citizenship, open- } \\
\text { ness, sociability and responsibility, that is, the basis of pluralistic liberal democracy } \\
\text { is the latest trend in the interpretation of the functions of the CS. Within it, the greatest } \\
\text { efforts are to rely on increased economic efficiency and general welfare }\end{array}$ \\
Electoral & Intermediary &
\end{tabular}

Note: * compiled by the author on the basis of [34]

In our opinion, the model of the "electoral" CS is the most promising in the modern conditions of development of society and the one that most fully meets its challenges, because it essentially includes the most important characteristics of the previous two models. Thus, the function of the counterweight to the "democratic" CS is to lobby groups of interests of their own interests (including and especially economic ones) through political participation in the life of the state, while adherence to the basic principles of a pluralistic liberal democracy is at the heart of modern socially responsible entrepreneurship. 
The need for the development of the CS in this direction is also written about by the theorists of modern egalitarism (French: egalité - equality) - a concept that proposes the creation of a society with equal opportunities for managing and granting access to material wealth to all its members), liberalism and participatory democracy.

Modern understanding of the CS implies the presence of a whole set of essential features. The main thing, in our opinion, is that the CS is a society of free individuals. In economic terms, this means that only people, who have a home and reliable job, can be citizens, who can defend their rights [35]. That is, the existence of political freedom is not possible without material security, so a special place is given to the economic component.

It should be noted that, despite the awareness of the role of the economy for the CS, and on the contrary, the question remains as to the limits of their interaction, as well as the social sphere that it includes [33]. Thus, representatives of the classical theory associate the CS with the economy outside the state, and those of liberal theory imply the existence of a free market exchange, which is based on private property (this refers to the free from the state economic activity of free individuals). Moreover, the economic sphere determines the very existence of the CS, being exactly at its core [36].

Accordingly, there are several theories that attempt to explain the interconnection between the spheres of the CS and the economy. Among them is the widely used theory of A. Gramsci, who believed that the CS is outside the domain of domination of the economy and the state [37]. Such an understanding is defined as functional, that is, one that distinguishes in a social life those or other spheres depending on their functions. The first place belongs to the public sphere and the sphere of participation.

The three-member concept of Gramsci is concentrated on the society itself, and not on the state (Hegel) or the economy (Marx). The basic components of such a society are communications and public associations. Economic and political components fulfill the functions of stabilizing the social structure and play the role of peculiar receptors, receiving the signals of the CS, directed towards the state and the economy.

Public associations, like the entire public sphere, are common institutions for both the public and political spheres, and there are no clear boundaries between these spheres: they are interpenetrating and, thus, affect each other. A significant difference in the sphere of the CS from other spheres is that within it the development of democracy is faster and more intense than in the spheres of economy and politics, since communication mechanisms are the priority (media, political associations and clubs, parliamentary debates and hearings, public discussion, etc.).

However, we believe that the CS in the three-part concept of Gramsci is not an alternative to the state and the market, because it represents an integral unity of them. Only when these three spheres (the CS, the market, the state) exist, complement and control one another, we can speak about both civil and personal freedoms which are connected with the existence of the joint institutes of the CS. Thus it can be argued, that in Fig. 1 the existence of these freedoms is possible only at the intersection of three spheres, that is, in the darkest section. In addition, the three-part concept of Gramsci, in our opinion, cannot be practical, because it ignores such an important component as the private sphere.

The model, proposed by the London Centre for Civil Society, is more complete, as this model considers it as an independent sector, which is in a ratio of not two, but with three spheres: political (state), economic (business) and private (family) (Fig. 1) [28].

Although today this model is considered to be most consistent in scientific circles, we cannot think of it as an ideal one, because it defines a specific division of subjects and functions within each sphere. Nevertheless, in practice, it is possible for subjects to move from sphere to sphere, depending on the role they perform, and the purpose of the activity. For example, entrepreneurs traditionally relate to the economic sphere, but they will act as subjects of the CS, seeking exemption from taxation, therefore, in this case, we consider the approach that considers the CS as a space between other sectors (state, business, family), thus subjects, related to specific spheres, can also function in the CS, much more appropriate [6] (Fig. 1). 


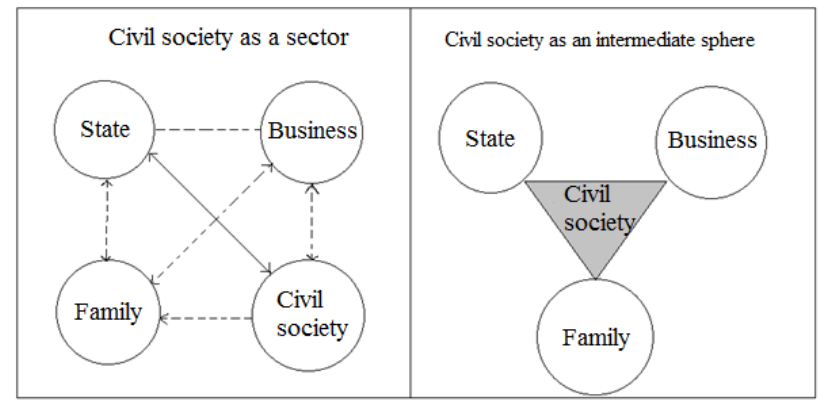

Fig. 1. SC as a sector and as an intermediate sphere [28]

However, in our opinion, in spite of the fact that these models of the correlation of the CS with the other spheres, depicted in Fig. 1, are far more sophisticated in comparison with the Gramsci concept, they still do not meet the requirements of the present time. This is due to the fact that today the CS is characterized by certain principles, namely:

1) the principle of universal egalitarian law, which provides a certain minimum of external freedoms and dignity for each person (legal sphere);

2) the principle of private property (economic sphere);

3) the principle of personally recognized internal human freedom (personal and spiritual sphere) [38].

We strongly believe that ensuring the implementation of these principles is possible if we consider the interaction of the political, economic, private and public spheres from a different angle, namely as an environment that enables the interaction of the state, business and family in accordance with their natural functioning (Fig. 2).

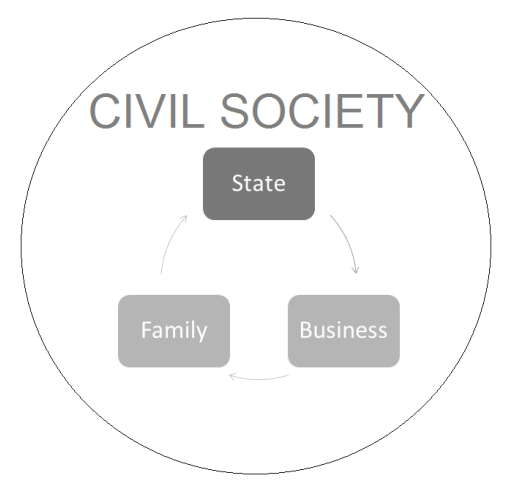

Fig. 2. CS as a sphere of interaction of the state, family and business

Under such an approach, the peculiarities of CS that are related to the fundamental characteristics of the CS which is freedom and characteristic of the economy are best brought to light, namely:

- equality and security of all forms of ownership, especially private (in its group and individual forms);

- economic freedom of citizens and their associations, other subjects of industrial relations in the choice of forms and the implementation of entrepreneurial activity;

- freedom and voluntarity of work on the basis of free choice of forms and types of work [20].

Given the importance of each of these elements of economic freedom, we shall consider them in more detail.

Nearly all scientists, who were engaged in the research of the CS, considered the right of ownership to be an inalienable right of every person, while comparing it with the right to life or freedom [39].

The CS, reflecting the mood of all people, is based on the will of an individual. We agree with this statement and strongly believe that it is private property that is the basis of the CS. At 
the same time, since the CS is inextricably linked with the rule of law, there is a need for legal safeguarding the inviolability of private property, enshrined in the legislation. In Ukraine, private property right is fixed at the level of the Constitution of Ukraine (CU) and the Civil Code of Ukraine. Thus, it is stated that "everyone has the right to own, use and dispose of their property" and "the right of private property is inviolable" in the CU [40], while the Civil Code of Ukraine (CCU) determines the subjects of private property (individuals and legal entities), types of property that may be privately owned and states that "The composition, amount and value of property that may be owned by individuals and legal entities are not limited" [41].

In our opinion, the existence of the $\mathrm{CS}$ is possible only when there are private property rights of a person or entity, since under such conditions a person is truly free and self-sufficient, since they can make independent decisions, be independent in the process of possession, use and disposal of their property, results their intellectual and creative activity, which is guaranteed by the CU [40].

The right to entrepreneurship in Ukraine is enshrined in the Constitution of Ukraine, as well as the Commercial Code of Ukraine. Thus, Art. 42 of the Constitution states that everyone has the right to entrepreneurial activity, which is not prohibited by law. The Commercial Code defines the basic principles of business activity that are in line with the principles of the CS, namely:

- free choice of activities;

- independent formation of the program of activity;

- free hiring of employees;

- free disposal of profits, remaining after making payments, prescribed by law, etc. [41].

Despite this, we consider that the freedom of entrepreneurship in Ukraine is specific because of the large number of restrictions on small and medium-sized enterprises, as well as its significant bureaucratization from the moment of registration of the enterprise, in which it should be noted, that the situation is not getting better over time. Undoubtedly, such tendencies do not meet the standards of the developed economy and slow down the development of the CS in Ukraine.

The realization of the rights and freedoms of an individual is real in a society, in which the individual has access to means of production and has a fair remuneration for personal labor [20]. A society of this type can exist under a number of conditions, among which two are directly related to the aforesaid, namely:

- workers are the owners of means of production and the results of their work;

- the aforementioned workers make up the majority of the adult population of the country.

\section{Conclusions}

Hence, the CS is a unique phenomenon that unites various institutions of the CS, greatly contributes to the development of democracy in the states, and also plays a significant role in the development of societies and economies. The inseparability of the research of the phenomenon of the CS with economics and economic processes is indicated not only by modern researchers, but also by those who were the first and, in essence, have become the creators of the theory of the CS, thus the economic component formed the basis of most of the further theories, explaining the essence of the CS. Among the most widely used modern models of CS, the most suitable for our study is the extended functional model of Edwards, because it allows you to take into account all aspects of the $\mathrm{CS}$, and also provides time and space comparability of the CS and its institutions.

It is important to study CS in conjunction with the economy and to consider it to be an area, within which the state, family and business interact, since this approach allows us to fully disclose the essence of its features and to ensure the implementation of the principles, inherent to the CS, including those, relating to economics.

\section{Acknowledgment}

This scientific article was produced at the Fil. Dr. Jan-U. Sandal Institute, Finstadjordet, Norway under the supervision of Prof. Fil. Dr. Jan-Urban Sandal, Executive Director and Owner at the Fil. Dr. Jan-U. Sandal Institute (Excellence in Science and Education). The paper was produced with the support of Summit Fund (ES-01-A-Sientific Entrepreneur Grant) awarded by Fil. Dr. Jan-U. Sandal Institute. 


\section{References}

[1] Merkel, W., Lauth, H. (1998). Systemwechsel und Zivilgesellschaft. Welche Zivilgesellschaft braucht die Demokratie? Aus Politik und Zeitgeschichte, 6 (7), 3-12.

[2] Schade, J. (2002). Zivilgesellschaft. Eine vielschichtige Debatte. Duisburg: INEF, 82.

[3] Keane, J. (Ed.) (1988). Despotism and Democracy - The Origins and Development of the Distinction between Civil Society and the State 1750 - 1850. Civil Society and the State - New European Perspectives. London, New York: Verso, 35-71.

[4] Marx, K., Engels, F. (1955). German Ideology. Collected Works. Moscow: Poliizdat.

[5] Putnam, R. (2000). Bowling Alone: The collapse and Revival of American Community. New York: Simon and Schuster. Available at: http://www.socialcapitalgateway.org/content/book/putnam-r-d-2000-bowling-alone-collapse-and-revival-american-community-new-york-simon-sc

[6] Croissant, A., Lauth, H., Merkel, W. (2000). Zivilgesellschaft und Transformation. Ein internationaler Vergleich. Systemwechsel Band. Zivilgesellschaft und Transformation. Opladen: Leske+Budrich, 9-49

[7] Merkel, W. (2000). Systemwechsel Band. Zivilgesellschaft und demokratische Transformation. Opladen: Leske+Budrich, 372.

[8] Edwards, M. (2004). Civil Society. Cambridge: Polity, 192.

[9] Spurk, C. (2010). Understanding Civil Society - History, debates, and contemporary approaches. Contribution to book Civil Society Peacebuilding. Available at: https://www.academia.edu/27420765/Understanding_Civil_Society

[10] Butkeviciene, E., Vaidelyte, E., Snapstiene, R. (2010). Role of Civil Society Organizations in Local Governance: Theoretical Approaches and Empirical Challenges in Lithuania. Viesoji politika ir administravimas, 33, 35-44.

[11] Cooper, R. (2018). What is civil society, its role and value in 2018? Helpdesk report. Available at: https:/assets.publishing. service.gov.uk/media/5c6c2e74e5274a72bc45240e/488_What_is_Civil_Society.pdf

[12] Lewis, D. (2013). Civil Society and the Authoritarian State: Cooperation, Contestation and Discourse. Journal of Civil Society, 9 (3), 325-340. doi: http://doi.org/10.1080/17448689.2013.818767

[13] Lorch, J., Bunk, B. (2016). Using civil society as an authoritarian legitimation strategy: Algeria and Mozambique in comparative perspective. Democratization, 24 (6), 987-1005. doi: http://doi.org/10.1080/13510347.2016.1256285

[14] Munene, J. W., Thakhathi, D. R. (2017). An analysis of capacities of civil society organizations (CSOs) involved in promotion of community participation in governance in Kenya. Journal of Public Affairs, 17 (4), e1668. doi: http://doi.org/10.1002/pa.1668

[15] Silverman, B. (2015). Recent Development, The Role of Civil Society Organizations in the United States Recently-Concluded CERD Review. Yale Journal of International Law, 40. Available at: https://ssrn.com/abstract=2629923

[16] Zeegers Paget, D., Renshaw, N., Droogers, M. (2017). What role can civil society organizations have in European health policy? European Journal of Public Health, 27 (suppl_4), 52-55. doi: http://doi.org/10.1093/eurpub/ckx155

[17] Filyk, N. (2003). Features of the formation of civil society in the modern world: a comparative approach (analysis). Entrepreneurship, Economy and Law, 12, 61-64.

[18] Homyakov, L. (2003). Paradoxes of civil society in Ukraine. Modernity, 12, 55-74.

[19] Polischuk, O. (2007). Civil society and its responcibility. Science. Religy. Society, 1, 142-148.

[20] Rabinovych, P. (2001). Fundamentals of the general theory of law and state. Kyiv: Atika, 176.

[21] Rozova, T., Barkov, V. (2003). Ideal and real in the ideas about the civil society. Human and Society, 3 (30), $44-50$.

[22] Aristotel (2000). Politika. Kyiv: Osnovy. Available at: http://litopys.org.ua/aristotle/arist.htm

[23] Tocqueville, A. (1848). De la Democratie en Amérique. Available at: https://gallica.bnf.fr/ark:/12148/bpt6k37010k.texteImage

[24] Kreide, R. (1992). VIII. Zur Rolle von Zivilgesellschaft und politischer Öffentlichkeit. Jürgen Habermas: Faktizität Und Geltung. Frankfurt: Suhrkamp, 399-467. doi: http://doi.org/10.1515/9783110434743-010

[25] Puhkal, O. (2007). The perspectives and the ways of improvement of the development of the civil society in Ukraine. Bulletin of the National Academy of Public Administration under the President of Ukraine, 2, 217-224.

[26] Sokolov, V. (2003). Civil society. Actors and performers. Viche, 4, $24-27$.

[27] Solyar, S. (2013). Civil society institutes. The forum of right, 1, 933-938.

[28] Paffenholz, T., Spurk, C. (2006). Civil Society, Civic Engagement, and Peacebuilding. Social Development Papers. Available at: http://siteresources.worldbank.org/INTCPR/Resources/WP36_web.pdf

[29] Chuvardynskii, O. (2007). Interests groups in civil society. Political management, 3 (24), 78-87

[30] Novoskolceva, L. (2008). Public-political unions: their role in the political life of society. Bukovinsky magazine, 1, 94-99.

[31] Alexander, J. C. (Ed.) (1998). Civil Society I, II, III: Constructing an Empirical Concept from Normative Controversies and Historical Transformations. In the book: Real Civil societies. Dilemmas of Institualization. London: Sage, 1-19.

[32] Marx, K., Engels, F. (1884). Origin of family, private property and state. Available at: https://www.marxists.org/archive/marx/ works/download/pdf/origin_family.pdf 
[33] Pavlenko, Y. (2008). Modern Civil Society. Voprosy Ekonomiki, 10, 96-107. doi: http://doi.org/10.32609/0042-8736-2008-1096-107

[34] Rozenblum, N. (2001). Civil society: liberalism and the moral influence of pluralism. Available at: http://www.ji.lviv.ua/ n21texts/rosenblum.htm

[35] Rosandu, J. (2008). Political system and civil society: a consensus of interests. Political management. Special issue, $100-108$.

[36] Karas, A. (2003). Philosophy of Civil Society in Classical Theories and Non-Classical Interpretations. Kyiv; Lviv: Publishing Center of Ivan Franko National University of Lviv, 250. Available at: http://www.experts.in.ua/baza/doc/download/grom_suspilstvo.pdf

[37] Tysa, I. (2011). Basic concepts of Antonio Gramsci’s political theory. Available at: http://vpered.wordpress.com/2011/12/29/ tysa-gramsci/

[38] Hodakyvskyy, M. (1998). Civil Society and the National State. Viche, 9, 34-46.

[39] Kopeychykov, V. (1998). Institutions of private property and entrepreneurship as the main components of civil society. Bulletin of APNU, 1 (12), 25-33.

[40] Constitution of Ukraine (1996). Verkhovna Rada of Ukraine No. 254к/96-BP. 28.06.1996. Available at: http://zakon1.rada.gov.ua/ laws/show/254 \%D0 \%BA/96-вр

[41] The Civil Code of Ukraine (2003). Verkhovna Rada of Ukraine No. 435-IV. 16.01.2003. Available at: http://zakon2.rada.gov. ua/laws/show/435-15/print1333689320534976 